\title{
分子系統解析によって明らかになったウドンコカビ （子のら菌門，ウドンコカビ目）表現形質の進化
} 高松 進 ${ }^{1 *}$

TAKAMATSU, S. ${ }^{1 *}$ (2014). Molecular phylogeny reveals phenotypic evolution of powdery mildews (Erysiphales, Ascomycota).

Key words: DNA シークエンス, ウドンコカビ科, 系統樹, 祖先形質, 派生形質

\section{緒言}

ウドンコカビは被子植物の葉, 茥, 花, 果実などに白粉状 のカビを生じる重要な植物寄生菌であり, 世界で 16 属, 約 900 種が知られている (Braun and Cook, 2012). すべての種 は生きた植物に寄生することのみによって生存可能な絶対 寄生菌であり, ウドンコカビの進化は宿主である植物の進 化と密接に関係しながら起こったと考觉られる。 ウドンコ カビのもら一つの特徵は, Leveillula, Phyllactinia, Pleochaeta 抒よ びQueiroziaの 4 属を除くすべての属が表皮寄生性を示すこ とである。菌系打よび分生子柄は宿主表面のみに存在し， 養分吸収器官である吸器のみを宿主表皮細胞に挿入する。 ウドンコカビがなぜ，どのようにしてこのような特殊な寄 生様式を獲得したのかを知ることは興味深い研究課題であ る. ウドンコカビはまた乾燥条件に強い, 植物寄生菌は通 常胞子発芽から感染までの期間，水滴あるいは湿潤状態を 必要とする。しかし，ウドンコカビは比較的低湿度条件下 でも発芽し，植物に感染することができる。

これまでに報告された分子系統解析結果ではウドンコカ ビは明瞭な単系統群を形成し，このグループ内にウドンコ カビ以外の生物が入ることはない（Mori et al., 2000a, b; Wang et al., 2006a, b). このことは, ウドンコカビがその祖先で 1 度 だけ絶対寄生性という寄生様式を獲得し, その後その性質 を失らことなく維持し続けてきたことを示唆している。こ れまでウドンコカビの系統関係や進化は括もに形態や宿主 との関連性などから推察されてきた（Arnaud, 1921; Blumer, 1933; Braun, 1987, 1995; Katumoto, 1973; Neger, 1901;
Raymond, 1927)。その議論の大部分は下記に示す性質のど ちらが祖先的でぞちらが派生的性質であるかに関するもの であった，例光ば，(1) ウドンコカビの子実体である閉子 のら殼中の子のら数（1 個か複数か)，(2) 子のら中の子の う胞子数（8個かそれよりも少ないか），(3）付属系の形態, （4）分生子形成様式（連鎖状に形成されるか 1 度に 1 個た け形成されるか)，（5）寄生様式（表皮寄生性か内部寄生性 か）などである。これらの議論については Braun（1987, 1995), Takamatsu（2004）㧊よび Braun and Cook（2012）に 述べられているのでここでは割愛する。 この総説では分子 系統解析に基づいた表現形質の進化について議論する.

\section{付属糸形態の進化}

大部分のウドンコカビは閉子のら殼の殼壁外層から伸長 する “付属系”と呼ばれる器官を形成する. 付属系は菌の種 類によって，菌系状，剛毛状，膨らんだ基部を持つ針状や こん棒状など様々な形状を示す，先端部は単純であったり， 二叉または三叉分枝したり，渦巻き状あるいは螺旋状に巻 いたりする．このため，付属系の形態は Léveillé（1851）以 来 150 年以上にわたってウドンコカビの属や種を見分ける重 要な形質と見なされてきた。 ウドンコカビの系統・進化に関 する従来の議論に扮いて，単純な菌系状の付属糸形態を最 も祖先的と見なす点ですべての研究者は一致していた [Braun (1981, 1987, 1995）, Braun and Cook（2012）打よび Takamatsu （2004）の総説を参照]

1 日に 1 個の分生子を形成（Pseudoidium 型） 乙，表皮寄生 性を示すウドンコカビのグループはErysiphe 連と呼ばれ,

\footnotetext{
1 三重大学大学院（† 514-8507 三重県津市栗真町屋町 1577） Graduate School, Mie University, 1577 Kurima-Machiya, Tsu-shi, Mie 5148507, Japan

* Corresponding author (E-mail: takamatu@bio.mie-u.ac.jp) この総説は先に Journal of General Plant Pathology の 79 巻 4 号の pp. $218 〜 226$ に掲載された総説（http://dx.doi.org/10.1007/s10327013-0447-5）の抄訳です。報文としてのプライオリティーはJGPP 掲載の総説にありますので，引用の際には本総説ではなく JGPP の総説を用いるようにご注意ください.
} 


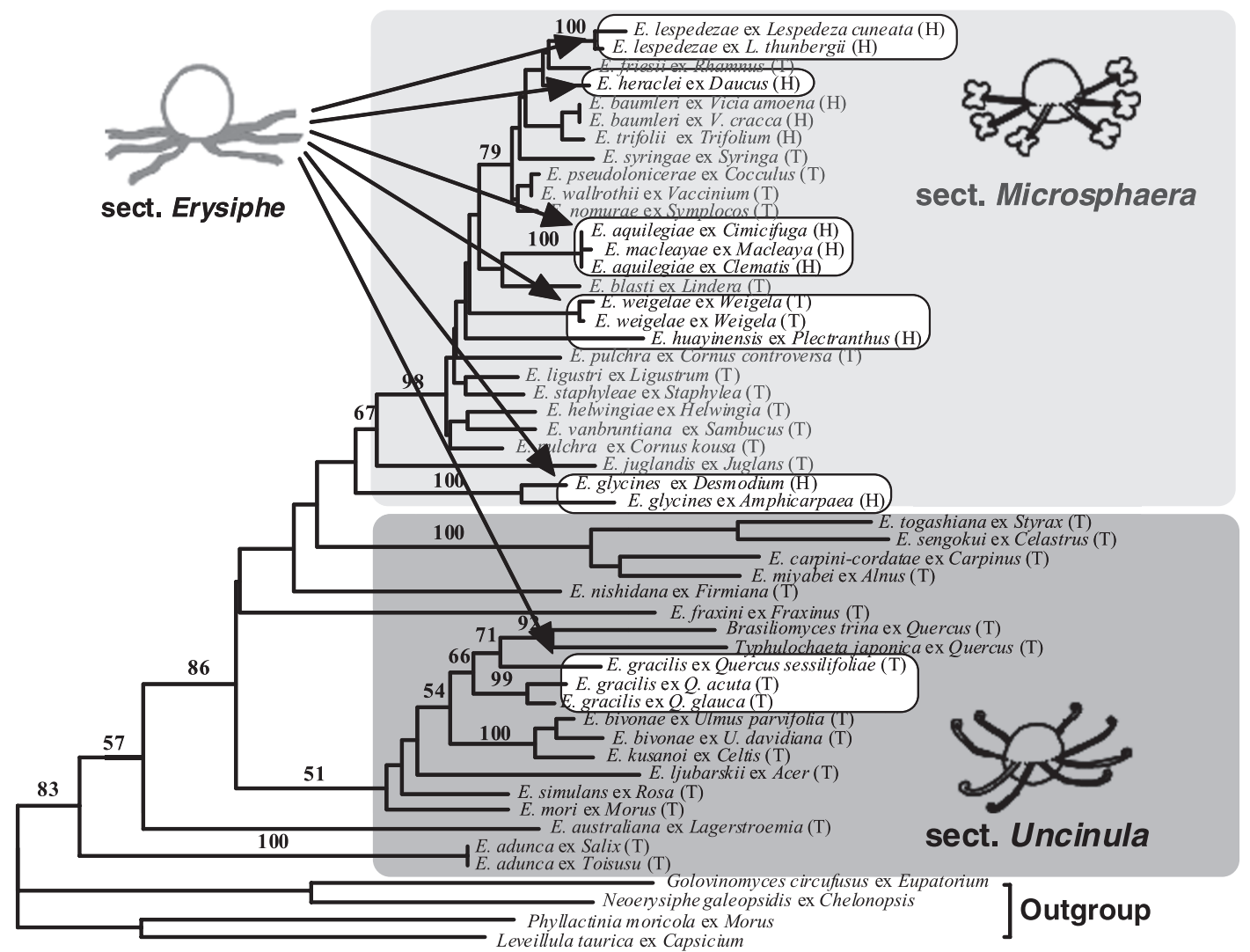

Fig. 1. Maximum parsimony tree of the tribe Erysipheae inferred from the nucleotide sequences of the rDNA ITS region. Numerals on the branches show bootstrap support values with 1000 replicates (only $>50 \%$ is shown). (T): tree or shrub; (H): herbaceous plant

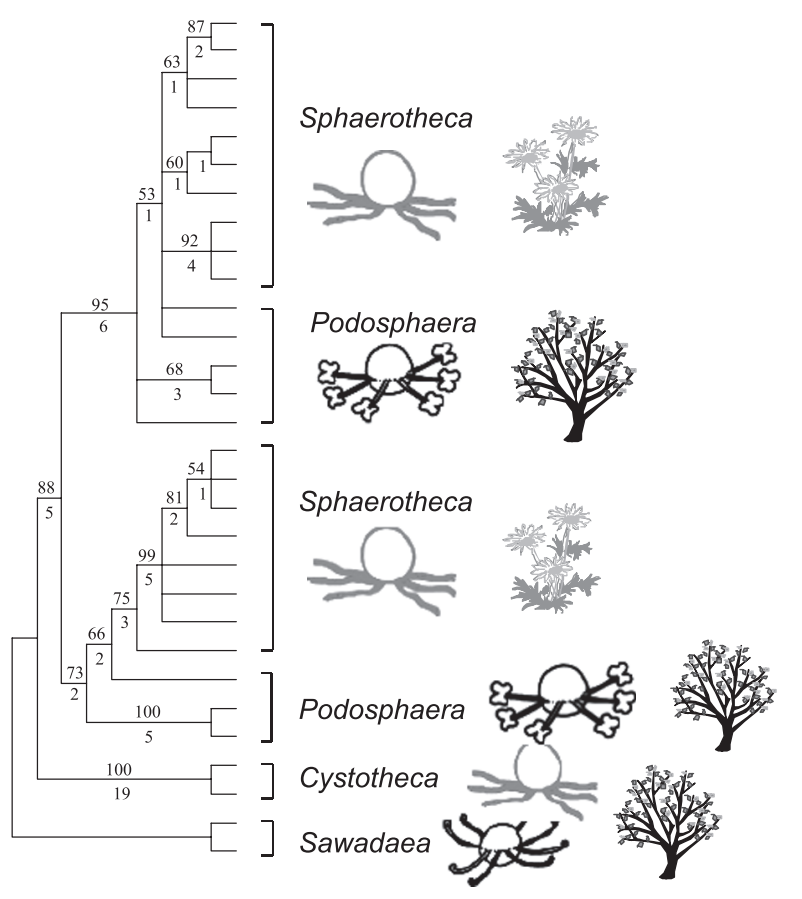

Fig. 2. Maximum parsimony tree of the tribe Cystotheceae inferred from the nucleotide sequences of the rDNA ITS region. Numerals on and under the branches show bootstrap support values with 1000 replicates (only $>50 \%$ is shown) and decay index, respectively. 
明瞭な単系統群を形成する (Fig. 1). Erysiphe 連はErysiphe 属 1 属から成り, Erysiphe 属は形態によって 5 つの節に 分けられる。このらち少数の種しかないTyphulochaeta 節と Californiomyces 節を除くと, 付属糸形態により 3 つの大な 節に分けられる. すなわち, 付属系先端部が数回二叉分岐す る Microsphaera 節, 付属系先端部が渦巻き状に卷くUncinula 節，そして菌系状で単純な Erysiphe 節である. Erysiphe 属 の分子系統解析結果によると, Microsphaera 節とUncinula 節はそれぞれ明瞭なグループを形成する. Uncinula 節は系 統樹の基部側に位置し, Microsphaera 節は Uncinula 節の 1 部から派生的に生じている (Mori et al., 2000a; Takamatsu et al., 1999). このことはMicrosphaera 型の付属糸形態が Uncinula
型の付属糸形態から派生して生じたことを示唆している. 一方, 菌糸状の付属糸を持つ種 (Erysiphe 節) は一つのグルー プを形成せず，系統樹全体に散在した（Fig. 1; Takamatsu et al., 1999).

この結果を解釈するには他のウドンコカビの系統解析が 必要だった. 分生子と分生子柄内に明瞭なフィブロシン体 を持つCystotheca 連は明瞭な単系統群を形成する (Fig. 2). Cystotheca, Podosphaera, Sphaerotheca (現在はPodosphaera 属 Sphaerotheca 節）扎よび Sawadaea の 4 つの属がこの連に所 属する. Podosphaera 属は先端部が数回二叉分岐する付属糸 を持ち, Sphaerotheca 属は菌糸状で単純な形態の付属糸を持 つ. 分子系統解析により, Podosphaera 属と Sphaerotheca 属 a
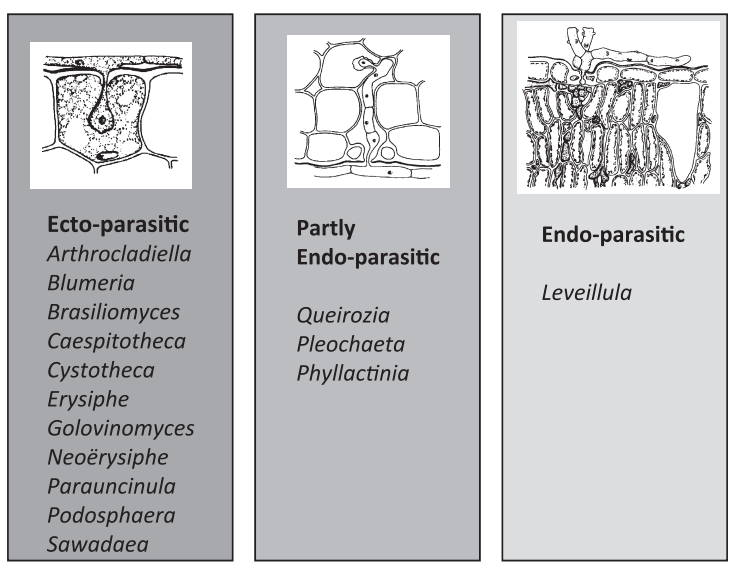

b

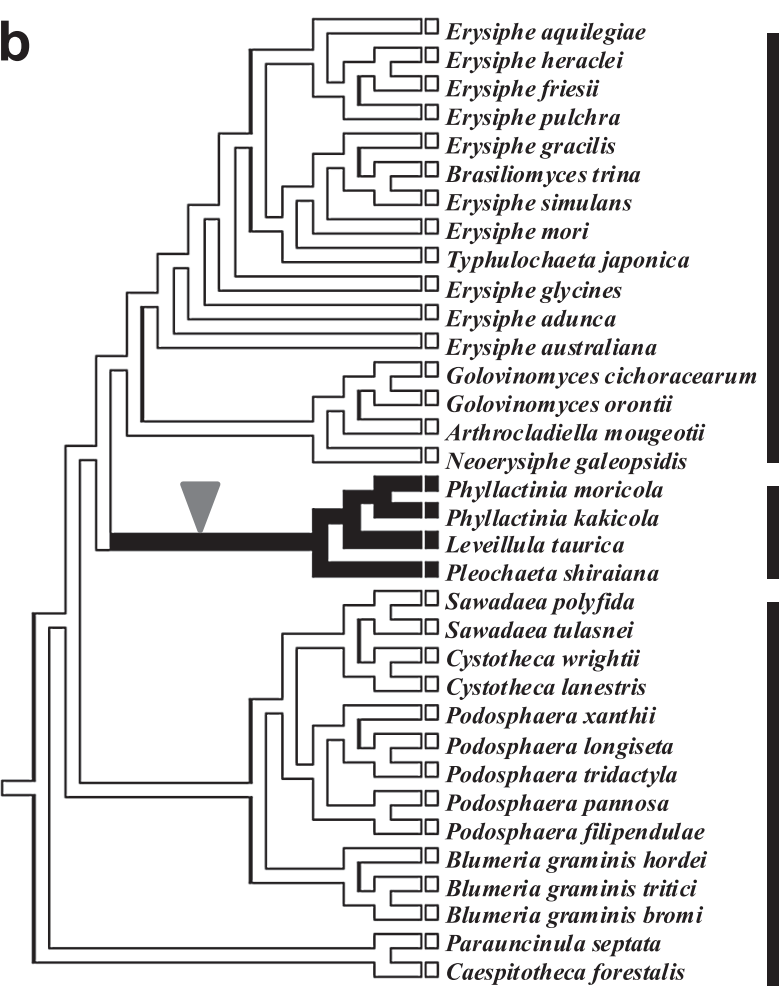

\section{Ecto-} parasitic

\section{Endo- parasitic}

\author{
Ecto- \\ parasitic
}

Fig. 3. a Grouping of powdery mildews by parasitism [reprinted, by permission, from Smith (1900) and Arnaud (1921)]. b Molecular phylogenetic tree of the powdery mildews inferred from the combined data set of the $18 \mathrm{~S}, 28 \mathrm{~S}$ and $5.8 \mathrm{~S}$ rDNA sequences. White and black branches indicate ecto-parasitic and endo-parasitic species, respectively. 
が 1 つの単系統群を形成し，その単系統群が 2 つ亜系統 群に別れることが明らかになった。その 2 つの亜系統群と もP Podosphaera 属と Sphaerotheca 属の種が含まれた (Takamatsu et al., 2000). すなわち, 分子系統解析はPodosphaera 属と Sphaerotheca 属といら 2 つの属を支持しなかった. 2 つ亜 系統群に拈いてPodosphaera 種は常に基部側に位置し, Sphaerotheca 種は派生的な場所に位置した.このことは Sphaerotheca 属が Podosphaera 属に似た祖先種から少なくと も2 回にわたって別々に進化したことを示唆している. 言 い換えると, この系統群に扣いて菌系状の付属糸形態が二 叉分岐状の付属糸形態から少なくとも2 回にわたって別々 に進化した.

Fig. 1 に戻ると, 付属糸形態の同様な進化が Erysiphe 連で も起こっていることがわかる. 一部の例外を除きUncinula
型の付属糸形態を持つ種と Microsphaera 型の付属糸形態を持 つ種は樹木あるいは低木などの木本植物に寄生し, 菌糸状 の付属糸を持つ種は草本植物に寄生する. このことは付属糸 形態の進化が宿主植物に適応した結果であることを示唆し ている。なぜこのよらな適応進化が起こったのかに関する 説明は Takamatsu（2004）で述べたのでここでは割愛する. これらの結果は菌系状で単純な付属糸形態が最も祖先的で あるといら従来の進化仮説を否定するものであった．菌系 状の付属糸は宿主植物への適応としての収斂進化の産物で あったのであろら。

\section{寄生様式の進化}

上記のように 16 属のウドンコカビのうち 12 属は表皮寄生 性で, 残りの 4 属, Phyllactinia, Leveillula, Pleochaeta および a

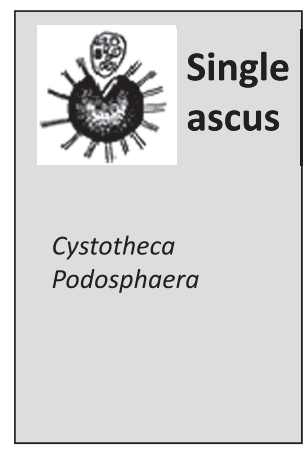

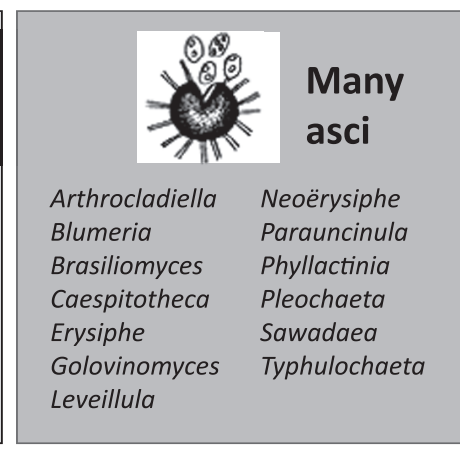

b

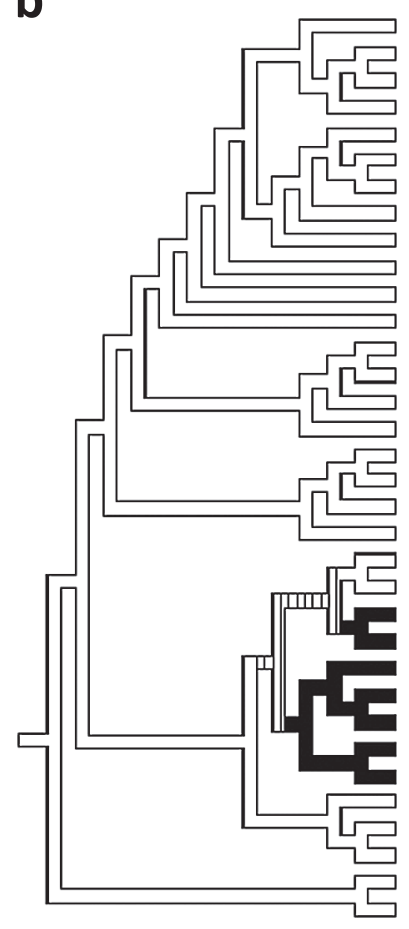

Erysiphe aquilegiae Erysiphe heraclei Erysiphe friesii Erysiphe japonica Erysiphe gracilis
Brasiliomyces trina Erysiphe simulans Erysiphe mori Typhulochaeta japonica Erysiphe glycines Erysiphe adunca Erysiphe australiana Golovinomyces cichoracearum Golovinomyces oronti Arthraocladiella mougeotii Neoerysiphe galeopsidis Phyllactinia moricola Phyllactinia kakicola Leveillula taurica Pleochaeta shiraiana Sawadaea polyfida Sawadaea tulasnei Cystotheca wrightii Cystotheca lanestris Podosphaera xanthii Podosphaera longiseta Podosphaera tridactyla Podosphaera pannosa Podosphaera filipendulae Blumeria graminis hordei Blumeria graminis tritici Blumeira graminis bromi Parauncinula septata Caespitotheca forestalis

\section{Hany
Masci}

Single

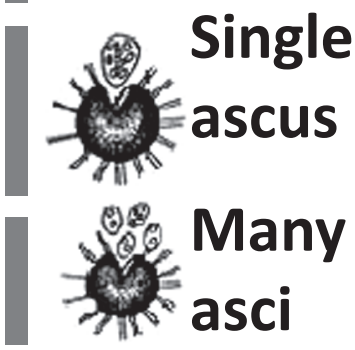

Fig. 4. a Grouping of powdery mildews by the number of ascus per chasmothecium. b Molecular phylogenetic tree of the powdery mildews inferred from the combined data set of the 18S, 28S and 5.8S rDNA sequences. White and black branches indicate many asci and single ascus species, respectively. 
Queirozia は内生菌糸を持つ内部寄生性である (Fig. 3a). この 4 属のらち, Phyllactinia, Pleochaeta 拈よび Queirozia は半内 部寄生性で, 菌系体の大部分は表生し, 表生菌糸から分生 子柄を生じる. 内生菌糸は気孔から侵入し柔細胞に吸器を 形成するが，その以上は伸長しない. Leveillulaのみが真性 の内生菌糸を生じ, この内生菌糸から分生子柄を生じ, 気孔 を通って植物体外へと伸長する. どちらの寄生様式が祖先 的かについて異なる意見が述べられてきた. Arnaud（1921） と Katumoto（1973） は内部寄生性の Leveillula が最も祖先 的で，そこから半内部寄生性が進化し，最後に表皮寄生性が 現れたと考えた，一方，Raymond（1927）, Blumer（1933） 扣よび Braun（1987）は内部寄生性を乾燥適応として進化し た派生形質であると考えた。

分子系統解析の結果, 内部寄生菌はPhyllactinia 連として まとまる明瞭な単系統群となった（Fig. 3b; Mori et al., 2000a).
このことは内部寄生性がウドンコカビの進化の歴史の中で 1 回のみ生じた派生形質であることを示唆している.さらに 詳細に解析すると, Pleochaeta とueirozia はPhyllactinia 連の 基部側に位置し，その一部から Phyllactinia 属が派生し，さ らに Phyllactinia 属の一部から Leveillula 属が進化したことが 明らかになった（Takamatsu et al., 2008). Leveillula 属の種数 颃よびその宿主植物数は, 地球上の他の地域に比べ西・中央 アジア报よび地中海地域で極めて多い（Amano, 1986; Hirata, 1968; Palti, 1988). このことはLeveillula 属の地理的起源がこ れらの地域であることを示唆する（Amano, 1986; Hirata, 1968; Takamatsu, 2013). 西・中央アジアから地中海にかけての地 域は地球上で最も乾燥した地域であり，このことは内部寄生 性が乾燥適応の結果生じたといら Raymond（1927）やBraun （1987）の仮説を支持している.

Fig. 5. a Grouping of powdery mildews by conidiogenesis (Drawing by Jamjan Meeboon). b Molecular phylogenetic tree of the powdery mildews inferred from the combined data set of the $18 \mathrm{~S}, 28 \mathrm{~S}$ and $5.8 \mathrm{~S}$ rDNA sequences. White and black branches indicate species of Euoidium-type and Pseudoidiumtype, respectively.
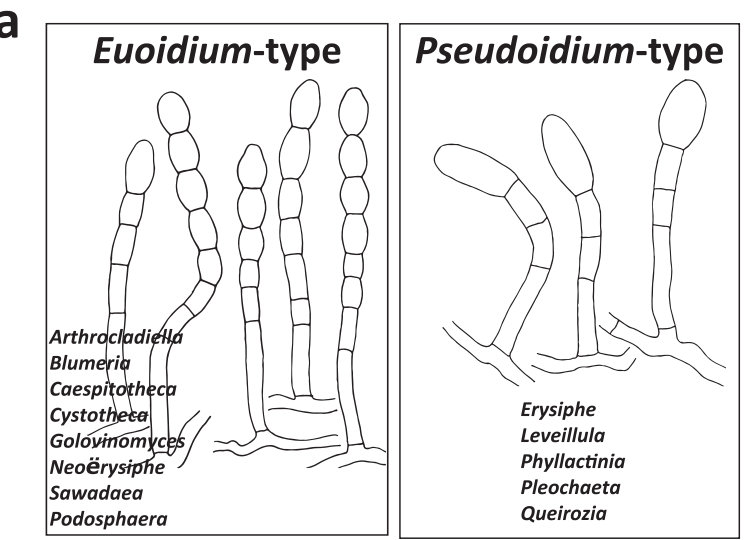

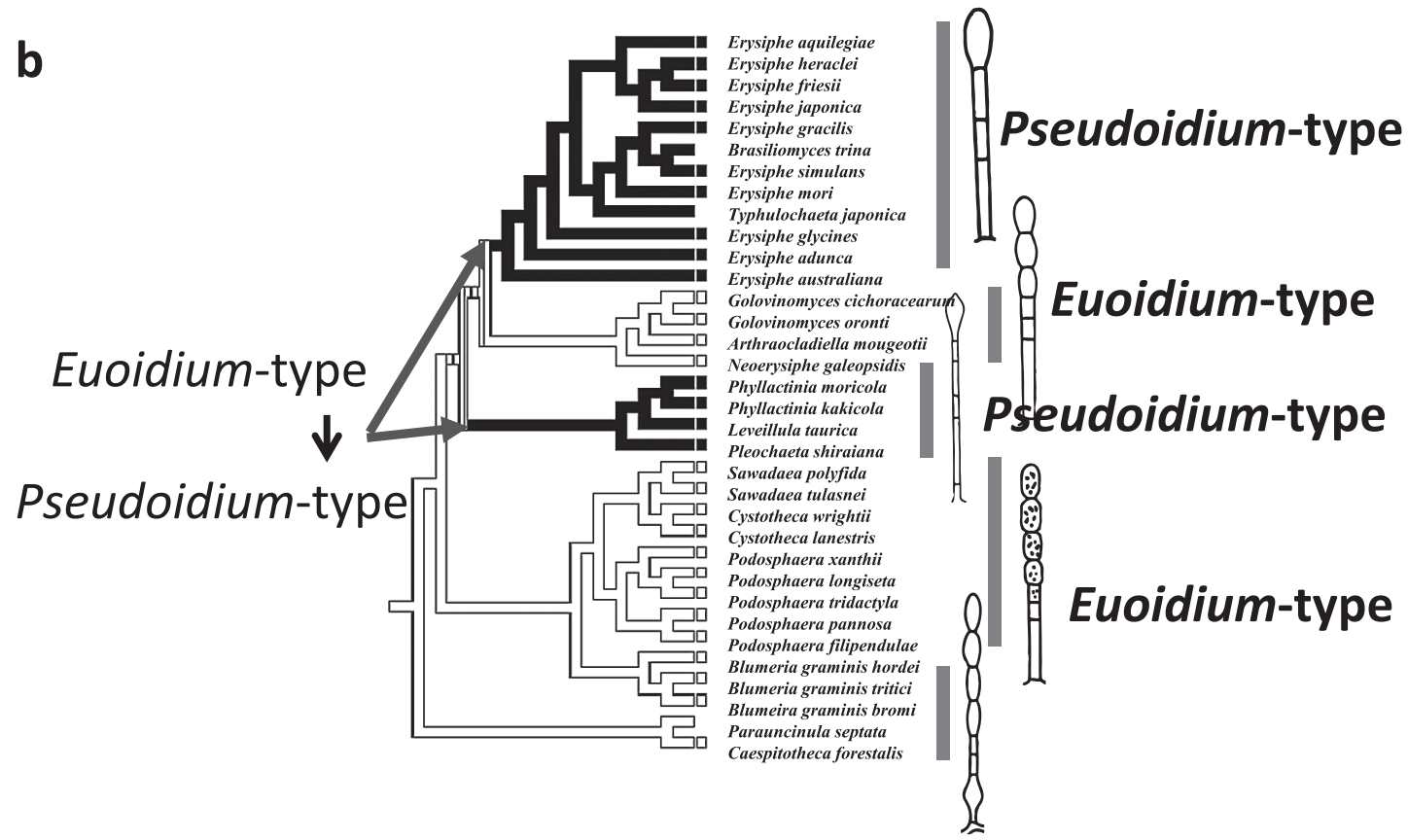




\section{閉子のう殼中の子のう数}

ウドンコカビは閉子のら款中の子のら数によって大きく 2つのグループに分けられる. Cystotheca と Podosphaera (Sphaerotheca を含屯) の 2 属は閉子のう殼中に 1 個の子のう を有する. 残り 14 属の閉子のう殼内には複数の子のらが含 まれる (Fig. 4a)。Neger（1901）は菌系状の付属系を持ち 閉子のう殼中に 1 個の子のうを持つSphaerotheca 属（現 Podosphaera 属 Sphaerotheca 節) ガウドンコカビで最も祖先 的であると考光た，一方，他の菌学者達（Jaczewski, 1927; Blumer, 1933; Braun, 1987） は菌系状の付属糸之複数の子の らを有するErysiphe 様の菌を最も祖先的と考光た．分子系統 解析により, 複数子のうが祖先的形質で, 単数子のらは複数 子のらから派生的に生じた派生形質であることが明らかに なった（Fig. 4b; Mori et al., 2000a). Fig. 4b で単数子のう 形質は単系統ではなく側系統になっているが，KishinoHasegawa テスト（Kishino and Hasegawa, 1989）では単数子 のら形質の単系統性は有意に棄却されないので，この形質が 1 回の進化によって生じたと考学る方が妥当であるう.最近, 単数子のらを持つ種が Erysiphe 属 Microsphaera 節にも存在 することが明らかになった（Shiroya et al., 2008）。このことは 子のう数の単数化が Erysiphe 属でも少数例ながら起こった ことを示唆している.

\section{分生子形成様式}

ウドンコカビは分生子の形成様式によって二つのグルー プに大別される。一つのグループは Erysiphe 属と内部寄生 菌が所属するグループで，1 日に 1 個の分生子のみが形成さ れるグループ (Pseudoidium 型)。もら一つは連鎖状に分生 子を形成する，すなわち 1 日に数個の分生子が分生子柄上 に形成され，連なって成熟するタイプ (Euoidium 型) であ る (Fig. 5a; Braun and Cook, 2012). Blumer（1933）と Heluta （1981）は Euoidium 型を祖先形質と見なし，Braun（1987）は Pseudoidium 型を祖先形と考光た。分子系統解析の結果, Euoidium 型が祖先形質で，Pseudoidium 型はあとで出現した ことが明らかになった（Fig. 5b; Mori et al., 2000a)。 Fig. 5b はPseudoidium 型が Erysiphe 連に至る系統と Phyllactinia 連 に至る系統の 2 回，別々に生じたことを示唆している。乙 かし，Golovinomyces 連（Euoidium 型）を含むこれら 3 つの 連の分岐順序はこの解析からは不明瞭であり，この問題を 明らかにするためにはさらに詳細な解析が必要であろら。

\section{形質進化のまとめ}

上記の結果を総合してウドンコカビの形質進化の歴史を Fig. 6 のようにまとめることができる. この図からウドンコ カビの進化にある種の方向性があることが示唆される。すな

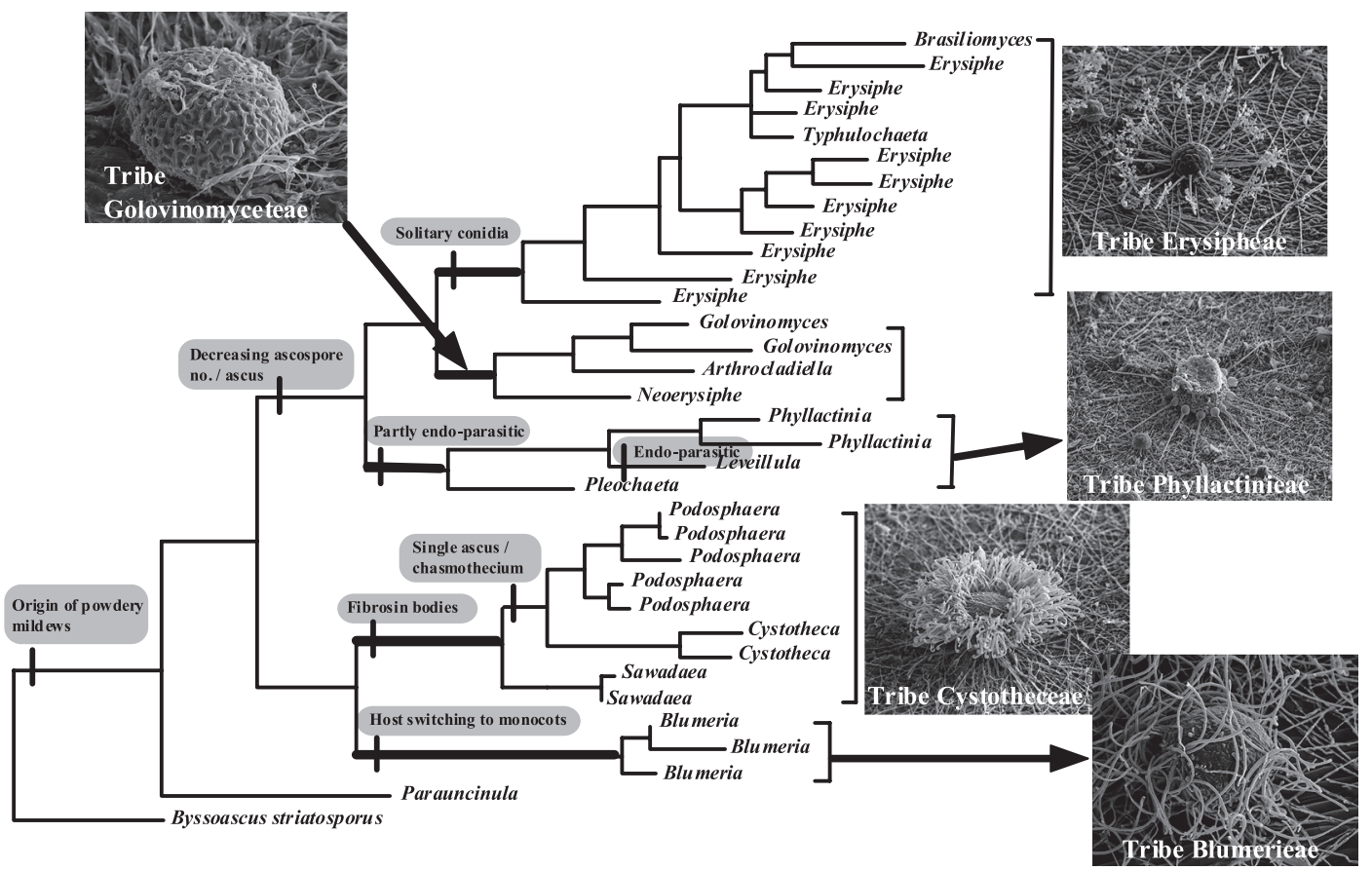

Fig. 6. Summary of phenotypic evolution of powdery mildews 


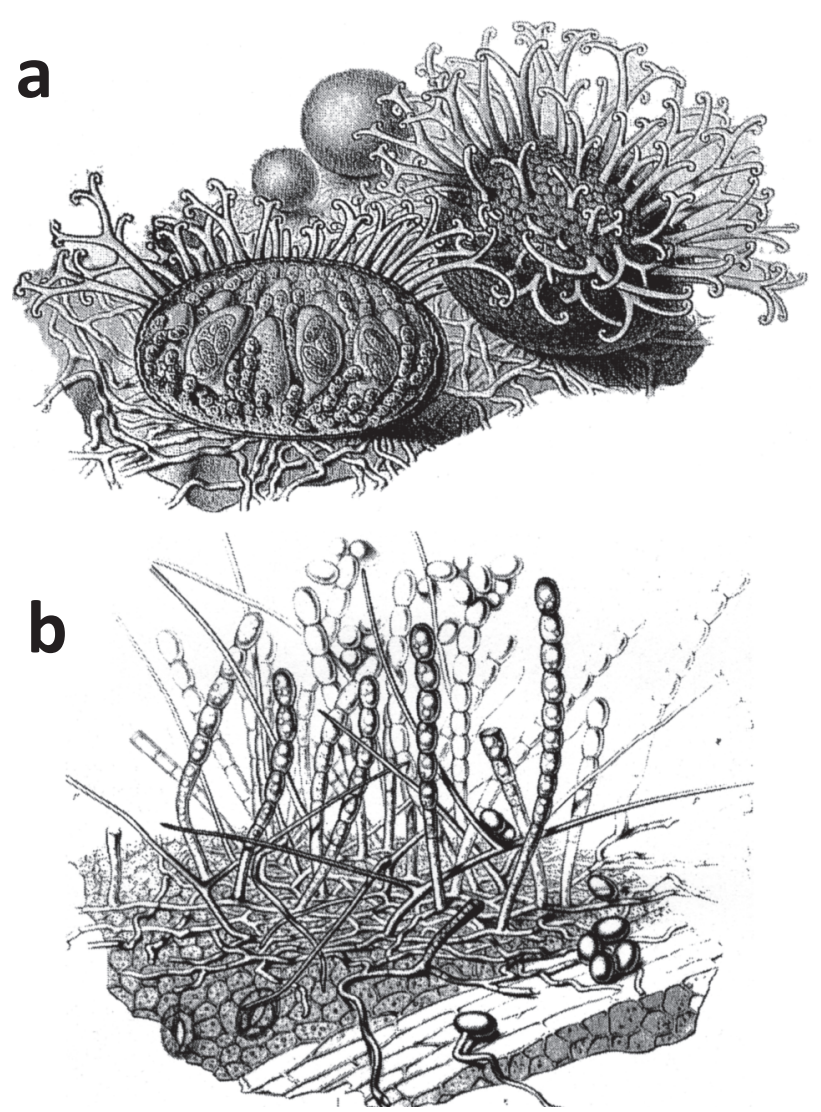

Fig. 7. Drawings of powdery mildews illustrated by Tulasne and Tulasne (1861). This is close to the putative ancestral feature of the powdery mildews. a Teleomorph. b Anamorph.

わち, 繁殖体数の減少である. 例えばCystotheca と Podosphaera に至る系統で複数子のらから単数子のらへの子のら数の減 少が起こった。複数子のらタイプのグループでは, 子のら 中の子のう胞子数の減少（8 個からそれより少ない数へ）が Erysiphe 連, Golovinomycs 連执よびPhyllactinia 連へ至る系統 で起こった. Golovinomycs 連とPhyllactinia 連では子のらあ たりの子のら胞子数は 2 個まで減少した. 分生子世代では, Euoidium 型 (連鎖型) から Pseudoidium 型（単生型）への分 生子形成様式の進化が Erysiphe 連と Phyllactinia 連へ至る系 統で起こった. 興味深いことに, 閉子のら殼中の子のら数 の減少は子のら中の子のら胞子数の現象が起こった系統と は異なる系統で起こっている. ウドンコカビの進化の過程 で繁殖体数の減少が起こった理由は明らかでない.

\section{ウドンコカビの祖先形質}

形質進化を共通祖先へと逆にたどることによりウドンコ カビの祖先形質を推察することが可能である. Tulasne and Tulasne（1861）によって発表されたスケッチ（Fig. 7）は今
回推察されたウドンコカビの祖先形質に似ている. 多少の 推察を交えながら復元した祖先形質は以下のようになるで あろら．完全世代では，大型の閉子のら殼の肩部かららず 巻き状に巻いた先端部をもつ付属糸が多数伸長する. 閉子 のら殼内には 8 個の子のら胞子を持った子のらが多数含ま れる. 分生子世代では, 分生子は連鎖状に形成され (Euoidium 型)，明瞭なフィブロシン体を持たなかったであろら。寄生 様式は表皮寄生であったと考えられる.

\section{謝辞}

本稿を草するにあたり有益な助言を賜った Martin-Luther 大学の Uwe Braun 博士に感謝する。本研究の一部は科研費 基盤 C（23580061）の助成を受けて行った.

\section{引用文献}

Amano, K. (1986). Host range and geographical distribution of the powdery mildew fungi. Japan Scientific Societies Press, Tokyo.

Arnaud, G. (1921). Étude sur les champignons parasites. Ann. Épiphyt. 7: 1-115.

Blumer, S. (1933). Die Erysiphaceen Mitteleuropas unter besonderer Berücksichtigung der Schweiz. Beitr. Krypt.-Fl. Schweiz. 7: $1-483$.

Braun, U. (1981). Taxonomic studies in the genus Erysiphe I. Generic delimitation and position in the system of the Erysiphaceae. Nova Hedwigia 34: 679-719.

Braun, U. (1987). A monograph of the Erysiphales (powdery mildews). Beih. Nova Hedwigia 89: 1-700.

Braun, U. (1995). The powdery mildews (Erysiphales) of Europe. G. Fischer Verlag, Jena.

Braun, U. and Cook, R.T.A. (2012). Taxonomic manual of Erysiphales (powdery mildews), CBS Biodiversity Series No 11. CBS, Utrecht.

Heluta, V.P. (1981). Mesto roda Podosphaera Kunze v sheme vozmozhnyh filogeneticheskih vzaimosvyazey rodov muchnistorosyanyh gribov. Novosti. Sist. Vyssh. Nizsh. Rast. 1979: 200 209.

Hirata, K. (1968). Notes on host range and geographic distribution of the powdery mildew fungi. Trans. Mycol. Soc. Jpn. 9: 73-88.

Jaczewski, A.A. (1927). Karmanny opredelitel' gribov. Vyp. 2. Muchnisto-rosyanye griby. Mikologicheskaya Laboratoriya Imeni Professora A.A. Jaczewskogo, Gosudarstvennogo Instituta Opytnoy Agronomii, Leningrad.

Katumoto, K. (1973). Notes on the genera Lanomyces Gäum. and Cystotheca Berk. et Curt. Rept. Tottori Mycol. Inst. 10: 437-446.

Kishino, H. and Hasegawa, H. (1989). Evaluation of the maximum likelihood estimate of the evolutionary tree topologies from DNA sequence data, and the branching order in Hominoidea. J. Mol. Evol. 29: 170-179.

Léveillé, J.H. (1851). Organisation et disposition méthodique des espèces qui composent le genre Erysiphé. Ann. Sci. Nat. Bot., Ser. 3 15: 109-179.

Mori, Y., Sato, Y. and Takamatsu, S. (2000a). Evolutionary analysis 
of the powdery mildew fungi using nucleotide sequences of the nuclear ribosomal DNA. Mycologia 92: 74-93.

Mori, Y., Sato, Y. and Takamatsu, S. (2000b). Molecular phylogeny and radiation time of Erysiphales inferred from the nuclear ribosomal DNA sequences. Mycoscience 41: 437-447.

Neger, F.W. (1901). Beiträge zur Biologie der Erysipheen. Flora 88: 333-370.

Palti, J. (1988). The Leveillula mildews. Bot. Rev. 54: 423-535.

Raymond, J. (1927). Le blanc du chêne. Ann. Epiphyt.13: 94-129.

Shiroya, Y., Nakashima, C. and Takamatsu, S. (2008). Erysiphe monascogera sp. nov., an unusual powdery mildew fungus found on fruits of Styrax japonica. Mycoscience 49: 199-206.

Smith, G. (1900). The haustoria of the Erysiphaceae. Bot. Gaz. 29: 153-184.

Takamatsu, S., Hirata, T., Sato, Y. and Nomura, Y. (1999). Phylogenetic relationships of Microsphaera and Erysiphe section Erysiphe (powdery mildews) inferred from the rDNA ITS sequences. Mycoscience 40: 259-268.

Takamatsu, S., Hirata, T. and Sato, Y. (2000). A parasitic transition from trees to herbs occurred at least twice in tribe Cystotheceae (Erysiphaceae): evidence from nuclear ribosomal DNA. Mycol.
Res. 104: 1304-1311.

Takamatsu, S. (2004). Phylogeny and evolution of the powdery mildew fungi (Erysiphales, Ascomycota) inferred from nuclear ribosomal DNA sequences. Mycoscience 45: 147-157.

Takamatsu, S., Inagaki, M., Niinomi, S., Khodaparast, S.A., Shin, H.D., Grigaliunaite, B. and Havrylenko, M. (2008). Comprehensive molecular phylogenetic analysis and evolution of the genus Phyllactinia (Ascomycota: Erysiphales) and its allied genera. Mycol. Res. 112: 299-315.

Takamatsu, S. (2013). Origin and evolution of the powdery mildews (Ascomycota, Erysiphales). Mycoscience 54: 75-86.

Tulasne, L.R. and Tulasne, C.C. (1861). Selecta fungorum carpologia 1. Paris.

Wang, Z., Binder, M., Schoch, C.L., Johnston, P.R., Spatafora, J.W. and Hibbett, D.S. (2006a). Evolution of helotialean fungi (Leotiomycetes, Pezizomycotina): a nuclear rDNA phylogeny. Mol. Phylogenet. Evol. 41: 295-312.

Wang, Z., Johnston, P.R., Takamatsu, S., Spatafora, J.W. and Hibbett, D.S. (2006b). Toward a phylogenetic classification of the Leotiomycetes based on rDNA data. Mycologia 98: 10651075 . 